\title{
Orientacje sprawcze i wspólnotowe współczesnej młodzieży
}

\section{KEYWORDS}

social orientations, youths, globalization

\begin{abstract}
Peret-Drążewska Paulina, Orientacje sprawcze i wspólnotowe współczesnej młodzieży [Causative and Community Orientations of Contemporary Youths]. Kultura - Społeczeństwo - Edukacja nr 2(6) 2014, Poznań 2014, pp. 135-151, Adam Mickiewicz University Press. ISBN 978-83232-2869-1. ISSN 2300-0422

The primary aim of the article is a discussion on the youth's orientation in the social aspects of life in theoretical and empirical perspective. The research subject raised in this article is to show the image of the today's youths from the perspective of peers by the designation of some aspects, especially social orientations, that are being only fragments of the necessary conditions to seize the situation of young people.
\end{abstract}

\section{Wprowadzenie}

Zjawiska socjokulturowe, których podłoże stanowi jakość relacji między jednostką a teraźniejszą rzeczywistością społeczno-kulturowa, kreowane są w znacznej mierze przez aktualnie panujące warunki środowiskowe. Niniejszy dyskurs zależny jest od specyfiki czasów płynnej nowoczesności (zob. Bauman, 2006), których głównym kreatorem stały się procesy globalizacyjne. Egzystencja w zaistniałej rzeczywistości społeczno-kulturowej jawi się jako ciąg nieskończonych zmian generowanych przez postępujące procesy związane z nurtem globalizacji. Uchwycenie istoty globalizacji, wyznaczającej kondycję współczesnego świata, jest podstawowym warunkiem zrozumienia szeregu trudności stojących przed jednostką zmagającą się niejednokrotnie z dylematami współczesności.

Procesy, które holistycznie kreują zjawisko globalnej ekumeny (zob. Hannerz, 2006) społeczno-kulturowej, wymagają ujmowania ich przez pryzmat kategorii zmiany, rozumianej jako brak stabilizacji, konieczność ciągłego dostosowywania 
się do wymogów „rozpędzonego” świata, mobilność i gotowość do podejmowania nowych wyzwań. Konieczność permanentnej, wymuszonej zmiany niesie za sobą niepewność, brak stałego odniesienia, co skutkuje lękiem i bezradnością wobec wyzwań ponowoczesności (zob. Giddens, 2010). Zaistniała współcześnie otwartość na zmianę prowadzi do zaniku rutyny, przewidywalności i powtarzalności. Odzwierciedla się to w jakości relacji międzyludzkich oraz relacji Ja - świat.

Przedstawiona powyżej płynnonowoczesna retoryka jest szczególnie obecna w dyskursie nad sytuacją współczesnej młodzieży. Relacje jednostki z rzeczywistością społeczno-kulturową intensyfikują się w okresie adolescencji, kiedy to młodzież świadomie podejmuje refleksję nad swoim miejscem w systemie społecznym w ramach realizacji szeregu tożsamościowych zadań rozwojowych. Głos młodego pokolenia stanowić może prognostyk przyszłych kierunków rozwoju współczesnych zjawisk socjokulturowych. $Z$ uwagi na podjęte rozważania teoretyczno-empiryczne należy również podkreślić, iż dążenie do podmiotowości intensywnie rozwija się w okresie adolescencji za sprawą przebudowy struktury Ja, która następuje głównie w zderzeniu własnej podmiotowości z realizacją zadań społecznych, kontaktach $\mathrm{z}$ rówieśnikami oraz relacjach $\mathrm{z}$ rodzicami. Podmiotowość młodzieży przekłada się bowiem na postrzeganie siebie oraz innych w nawiązaniu do grupy rówieśniczej. Zatem analiza autoprezentacji młodego pokolenia w kontekście relacji jednostka - społeczeństwo jest szczególnie istotna z wielu wskazanych powyżej względów. Niniejszy artykuł stanowi refleksję teoretyczno-empiryczną na ten temat ${ }^{1}$.

\section{Powiązania jednostki ze społeczeństwem. Rozważania na temat teorii podmiotowości}

Istotnym elementem partycypacji jednostek w życiu społeczno-kulturowym jest jakość relacji pomiędzy indywidualnymi dążeniami a potrzebami grup społecznych, które wyznaczają postrzeganie innych. Uczestnictwo w świecie społecznym sprawia, iż funkcjonowanie podmiotów go kształtujących jawi się w sposób dualistyczny, bowiem z jednej strony ludzie zorientowani są na realizację indywidualnych celów, z drugiej natomiast zobowiązani są do wypełniania zadań służących interesom życia społecznego, które wszyscy współtworzymy. Jednostkowa aktyw-

\footnotetext{
${ }^{1}$ Zaprezentowane w niniejszym artykule rozważania teoretyczne oraz wyniki badań empirycznych stanowią fragment rozprawy doktorskiej pt. Obraz wspótczesnej młodzieży postrzegany z perspektywy rówieśników napisanej przez autorkę pod kierunkiem prof. UAM dr hab. Agnieszki Cybal-Michalskiej w 2013 roku.
} 
ność wpływa na kształt struktury społecznej, jak też struktura społeczna rzutuje na jednostkową aktywność. Niniejsze założenia, będące podstawą teorii strukturacji A. Giddensa (2003), stanowią jeden z głównych elementów dyskursu o relacjach jednostki ze społeczeństwem, będących siłami determinującymi jakość partycypacji w zastanej rzeczywistości społeczno-kulturowej.

Układem relacji pomiędzy jednostkowym działaniem a jakością struktur społecznych (równocześnie pomiędzy tożsamością osobową a społeczną) zajmuje się również społeczna teoria podmiotowości. Podmiotowość zakłada „istotny, aktywny wpływ działań ludzkich na kształt struktury społecznej” - jak podkreśla Piotr Sztompka (1998: 13). Taki sposób ujmowania zagadnienia zakłada wzajemną relacyjność działań i struktur, co każe odrzucić przeciwstawność czynników obiektywnych i subiektywnych, a nakazuje traktować je łącznie, jako splot nieukierunkowanych powiązań przyczyn i skutków. Niniejsze ujęcie prezentowanej problematyki odrzuca jednoznaczny wpływ czynników mikrosocjologocznych, których reprezentantem są działania, na czynniki makrosocjologiczne, odzwierciedlające charakter struktur społecznych. Można zatem mówić o wzajemnym oddziaływaniu tychże czynników.

Egzemplifikacją takiego sposobu rozumienia relacji działanie - struktura jest dialektyczna teoria podmiotowości rozwinięta przez P. Sztompkę. Jej podstawowym założeniem jest „wzajemny wpływ działań i struktur” (Sztompka, 1998: 20-21), co prowadzi do odrzucenia determinizmu, kładącego nacisk na zewnętrzne czynniki. Związki pomiędzy działaniem a strukturą przybierają postać historycznego procesu osadzonego w konkretnych realiach czasoprzestrzennych. Proces ten ma charakter cykliczny. Podkreślone zostaje tu znaczenie aktywności ludzkiej, która ma właściwości strukturotwórcze. Dialektyczna teoria podmiotowości zakłada, iż „podmiot działający, który tworzy lub przekształca struktury społeczne, ma sam charakter społeczny” (Sztompka, 1998: 21). Sztompka uzasadnia tę tezę poprzez podkreślenie, iż przekształcanie struktur odbywa się zazwyczaj przez grupy społeczne, oraz fakt, iż działania te wymagają uzyskania akceptacji społecznej. Badacz zaznacza również, iż jednostkowe działania zawsze uwikłane są w kontekst struktury społecznej. Esencją dialektycznej teorii podmiotowości Sztompki jest założenie, iż podmiotowość stanowi „istotne kryterium postępu społecznego - podstawowy wymiar emancypacji człowieka” (Sztompka, 1998: 25).

Dialektyczna teoria podmiotowości wskazuje na istotność działania jednostek, które jest ujmowane w stosunku do struktury społecznej. Autor teorii podkreśla „strukturotwórczą, kreatywną rolę działań ludzkich” (Sztompka, 1998: 13), która 
odrzuca dotychczasowy pogląd nauk humanistycznych o nadrzędności struktur społecznych wobec działania jednostkowego. Sztompka rozumie „podmiotowość jednostek, klas, mas, ruchów społecznych jako zdolność (dysponowanie środkami, umiejętnościami, motywacjami) do wywierania wpływu na kształt struktury społecznej lub podmiotowość społeczeństwa - rozumianą jako podatność struktur społecznych na tego rodzaju wpływy (ich plastyczność, reformowalność)” (Sztompka, 1998: 13). Autor dialektycznej teorii podmiotowości rozwinął ją na podstawie analiz szeregu dotychczas sformułowanych koncepcji traktujących o podmiotowości, przedstawiając siedem założeń, które zaprezentuję poniżej (zob. Sztompka, 1998).

Pierwsza teza dotyczy wzajemnego, obustronnego wpływu działań i struktur, co wskazuje na odrzucenie determinizmu, mówiącego o wpływie warunków zewnętrznych na działania, oraz fatalizmu, czyli odgórnie ustalonych zdarzeń, na które jednostka ludzka nie ma wpływu. $\mathrm{Z}$ tego wynika kolejne założenie dialektycznej teorii podmiotowości, które w miejsce determinizmu i fatalizmu odwołuje się do aktywizmu, czyli wpływu aktywności ludzkiej na charakter struktur społecznych. Związek działanie - struktura przybiera postać procesualną, usytuowaną w konkretnym czasie historycznym. Aktywny podmiot, podejmujący działania, przekształcający struktury społeczne, samodzielnie osiąga wymiar społeczny. Sztompka uzasadnia niniejszą tezę, zauważając, iż znaczące historyczne wydarzenia, będące skutkiem działań wybitnych jednostek, mogły mieć miejsce jedynie za sprawą grupy społecznej, którą mobilizowała do działania owa wybitna jednostka. Innym jeszcze argumentem przytaczanym przez autora dialektycznej teorii podmiotowości jest uwaga o zależności kondycji podmiotu od miejsca w strukturze społecznej.

Kolejnym założeniem dialektycznej koncepcji podmiotowości jest istotność warunków społecznych, mających wpływ na kreowanie stopnia możliwości podejmowania działań jednostkowych. Kolejna teza mówi o istotności działań niezaplanowanych, spontanicznych, będących motorem napędowym wszelkich zmian strukturalnych. Ostatnie założenie przedstawianej koncepcji to ujmowanie podmiotowości jako „istotnego kryterium postępu społecznego - podstawowego wymiaru emancypacji człowieka" (Sztompka, 1998: 25).

Zagadnienie podmiotowości, według koncepcji P. Sztompki, ujmuje tę kategorię poprzez wpływ jednostkowego działania na struktury społeczne, ukazując szereg sprzeczności i niejasności tkwiących w polu znaczeniowym niniejszego pojęcia. Poprzez zestawienie wymienionych przeciwieństw (determinizm - fatalizm) w obrębie jednej, zwartej teorii, uwidacznia się wieloznaczność natury pojęcia „podmiotowość”, co czyni omawianą teorię szczególnie cenną i rzuca jasne światło na podjętą problematykę. 
Psychologiczny wymiar podmiotowości rozwinął Janusz Reykowski, odnosząc się do kategorii aktywności podmiotowej, którą definiuje on jako „aktywność kierowaną przez cele wybrane lub wytworzone przez sam podmiot" (Reykowski, 1998: 199). Podmiotowość ujmowana jest jako możliwość kreowania własnego życia przy sprowadzaniu do minimum wpływu czynników zewnętrznych, a skupianiu się na osobistej motywacji, własnych możliwościach oraz wewnętrznej potrzebie. Wewnętrzne, realne przekonanie o stopniu wpływu na własne losy, kształtowane już od dzieciństwa, zależne w dużej mierze od grupy społecznej, w której partycypuje jednostka, należy odróżnić od pożądanego stopnia wpływowości. Sytuacja, w której „poziom wpływu jest zgodny z osobistym standardem” (Reykowski, 1998: 200), daje jednostkom poczucie podmiotowości. Stopień poczucia wpływu jest znaczący dla kształtowania własnej tożsamości, bowiem - jak wyjaśnia J. Reykowski - „atrybucje efektów do siebie jako sprawcy stanowią podstawę powstawania przeświadczenia o sobie samym jako o istocie, która zdolna jest wywierać zamierzony wpływ na otoczenie, a tym samym posiadać zdolność do podmiotowej nad nim kontroli; przeświadczenia takie stają się składnikiem własnej tożsamości. Innymi słowy, integralnym składnikiem własnego Ja jest ujęcie siebie jako podmiotu, czyli dyspozycyjne poczucie podmiotowości” (Reykowski, 1998: 200-201). Dyspozycyjne poczucie podmiotowości to kategoria indywidualna, która zależna jest od: wiodącego obszaru życia realizacji podmiotowości, zasięgu, wpływu i wykształcenia. Mając na uwadze dychotomię między postrzeganym a pożądanym poziomu wpływu, autor wprowadził pojęcie „dążenia do podmiotowości”, które zdefiniował jako „aspiracje do tego, aby uzyskać obiektywne możliwości kontrolowania własnego losu i wpływania na otoczenie" (Reykowski, 1998: 201). Owa chęć zwiększenia wpływu na własne losy, przy ograniczaniu znaczenia czynników zewnętrznych, stanowi cechę charakterystyczną okresu adolescencji, kiedy to dążenie do podmiotowości jest szczególnie intensywne. Następuje wówczas ,wyodrębnienie siebie jako samodzielnej istoty o własnych przekonaniach i specyficznych dążeniach" (Reykowski, 1998: 202). Poczucie bezradności, pokora, pasywne podporządkowanie, poczucie uzależnienia - wszystko to potęguje ograniczenie poczucia podmiotowości.

Dążenie do podmiotowości², pomimo różnorodnej intensywności, cechuje wszystkich ludzi, co wywołuje szereg konfliktów na tym polu. Pierwszy z nich dotyczy faktu, iż indywidualne dążenie do podmiotowości realizuje się w zbiorowości społecznej, co rodzi niebezpieczeństwo zderzenia się z innymi jednostkowymi

\footnotetext{
${ }^{2}$ Zwarty przegląd koncepcji dotyczących problematyki podmiotowości w świetle różnych nauk społecznych przedstawiony został w: Cichocki, 2003.
} 
motywacjami i działaniami będącymi w obszarze podmiotowości innych. Konflikt ten jest wyraźnie widoczny w relacjach dziecko - dorosły lub w kontaktach międzyrówieśniczych, gdzie każda ze stron dąży do realizacji swoich podmiotowych celów. Ograniczenie własnej podmiotowości wynika często z konieczności realizacji zadań społecznych, które nierzadko stoją w opozycji do dążeń indywidualnych. Drugi rodzaj konfliktów wokół podmiotowości ma swoje źródło w przeciwstawnych dążeniach wewnętrznych jednostki: dążeniu do podmiotowości oraz dążeniu do uzależnienia się, które stanowią naturalną cechę charakterystyczną człowieka.

\section{Indywidualizm/kolekływizm jako postawy obrazujące stosunek jednostki do świata spolecznego}

Interesującą propozycję ujmowania relacji jednostka - społeczeństwo wysnuł J. Reykowski, który posługiwał się terminami indywidualizm i kolektywizm. W świetle podjętej problematyki, warto podjąć refleksję nad tymi orientacjami normatywnymi, które obrazują jednostkowe tendencje normatywne, jak również stosunek jednostki do świata społecznego. Według J. Reykowskiego, „ujęcie indywidualistyczne zakłada, że świat społeczny to zbiór odrębnych indywiduów, samodzielnie starających się o znalezienie optymalnych dla siebie form i warunków życia (...). Człowiek definiuje samego siebie jako wyodrębnioną jednostkę, której tożsamość zasadza się na ostrym rozróżnieniu Ja - inni” (Reykowski, Skarżyńska, Ziółkowski, 1990: 17).

Dokonując charakterystyki pojęcia indywidualizmu, Reykowski wymienia następujące wartości: „autonomia jednostki, niezależność emocjonalna, osobista inicjatywa, prywatność, wyraźna świadomość swojego ja (...). Jednostka sama odpowiada za siebie, sama określa, co jest dla niej dobre lub złe, względnie w innej interpretacji, sama rozpoznaje dobro i zło" (Reykowski, 1999: 25). Z drugiej jednak strony, czasy późnej nowoczesności ograniczają niezależność jednostek i ich poczucie kontroli nad biegiem zdarzeń życiowych. „W zaawansowanej nowoczesności indywidualizacja realizuje się $\mathrm{w}$ ramowych warunkach takiego procesu uspołecznienia, który w coraz większym stopniu uniemożliwia usamodzielnienie się: jednostka jest wprawdzie uwolniona od tradycyjnych więzi i źródeł zabezpieczenia bytu, musi za to wypełniać nakazy rynku pracy i wieść egzystencję konsumenta, podlegając odnośnym standaryzacjom i mechanizmom kontroli. Zamiast tradycyjnych więzi i form społecznych (klasa społeczna, rodzina nuklearna), występują wtórne instancje i instytucje, które wpływają na życiorys jednostki i czynią z niego 
- wbrew indywidualnej dyspozycji, która urzeczywistnia się jako forma świadomości - igraszkę mód, stosunków, koniunktur i rynków” - pisze Urlich Beck (2002: 197).

Z kolei kolektywizm zakłada, że: „jednostka nie jest bytem odrębnym, lecz częścią większej społecznej całości. Świat społeczny ujmowany jest jako układ stosunków między pewnymi społecznymi całościami (...). Tożsamość jednostki ujmowana jest w kategoriach przynależności grupowej. Jej tożsamość społeczna odgrywa rolę decydującą w określaniu siebie samej, granice Ja - my są nieostre, natomiast ostro zaznaczone są granice swój - obcy (my - oni). Rozwój orientacji normatywnych indywidualistycznych bądź kolektywistycznych wynika $\mathrm{z}$ rodzaju ukształtowanej tożsamości: osobistej lub społecznej. Jednakże oba te typy tożsamościowe są zrównoważone tak, aby jednostka przejawiała odpowiednie proporcje między chęcią upodabniania się do innych a chęcią odróżniania się od innych" (Reykowski, Skarżyńska, Ziółkowski, 1990: 18).

\section{Sprawczość/wspólnotowość jako wymiary spostrzegania spolecznego}

Obie siły, zarówno podmiot, jak też struktura, stanowią „motor napędowy” wszelkich działań człowieka skierowanych w kierunku realizacji celów osobistych lub wspólnotowych. Niniejsze zagadnienie stanowiło główny wątek pogłębionych analiz teoretycznych oraz badań empirycznych poczynionych przez Bogdana Wojciszke (2010), który traktuje owe kategorie jako podstawowe wymiary spostrzegania społecznego, noszące miano sprawczości i wspólnotowości ${ }^{3}$.

B. Wojciszke ujmuje kategorię sprawczości jako „wyraz egzystencji człowieka jako odrębnej jednostki, [jego] dążeń do indywiduacji i separacji poprzez realizację własnych celów, pewność siebie i ekspansję «Ja»; [sprawczość] wiąże się z koncentracją na sobie i dominacją. Osoby sprawcze to jednostki, u których dominują motywy osiągnięć, dominacji i niezależności” (Wojciszke, 2010: 39).

Z kolei wspólnotowość definiowana jest przez badacza jako „wyraz egzystencji człowieka jako części większego organizmu, [jego] dążeń do integracji z bytami społecznymi poprzez troskę o innych i współpracę; [wspólnotowość] wiąże się z koncentracją na innych, dbaniem o nich i intymnością. Osoby «wspólnotowe» to jednostki, u których dominują motywy intymności i afiliacji” (Wojciszke, 2010: 39).

\footnotetext{
${ }^{3}$ Terminy te zostały zaczerpnięte od Davida Bakana, który ujmował je jako odrębne wymiary egzystencji ludzkiej. Podaję za: Wojciszke, 2010.
} 
Jednostka będąca częścią powiązań społecznych przyjmuje postawę zmierzającą do podejmowania działań prowadzących do realizacji osobistego celu (orientacja sprawcza) lub też zmierzających do zrozumienia działań innych ludzi (orientacja wspólnotowa). Zatem „kategorie sprawcze i wspólnotowe są podstawowymi kategoriami opisu i wartościowania ludzi" (Wojciszke, 2010: 66), czyli niejako powiązane są również z cechami osobowości oraz stylami zachowań, które ujawnia podmiot.

W skład skali orientacji sprawczej wchodzą takie cechy, jak: pewność siebie, skuteczność, konsekwencja, ambicja, energia, przedsiębiorczość, siła woli, sprawność, przywódczość, siła przekonywania, przebojowość, zaradność, zdecydowanie (za: Wojciszke, 2010). Są to zatem atrybuty jednostkowe, które prowadzą jednostkę $\mathrm{w}$ stronę realizacji celów oraz korzyści indywidualnych.

$\mathrm{Z}$ kolei nastawienie indywidualne $\mathrm{w}$ połączeniu $\mathrm{z}$ grupowym ujawnia się u osób zorientowanych wspólnotowo, które posiadają takie cechy, jak: życzliwość, wyrozumiałość, opiekuńczość, skłonność do kompromisu, wrażliwość (zob. Wojciszke, 2010).

Powyższe rozważania odnosiły się do umiarkowanych form sprawczości i wspólnotowości, które nie prowadzą do negatywnych skutków odczuwanych przez podmiot oraz jego otoczenie społeczne. Zdarzają się jednak sytuacje, gdy owe niepożądane konsekwencje występują. Dlatego obok umiarkowanych form orientacji sprawczej i wspólnotowej, wyszczególnione zostały ich skrajne postaci, noszące miano niepohamowanej orientacji sprawczej oraz niepohamowanej orientacji wspólnotowej ${ }^{4}$.

Niepohamowana postać sprawczości rozumiana jest przez B. Wojciszke jako „koncentracja na sobie i własnych celach tak silna (niepohamowana przez wymogi wspólnotowości), że prowadzi do zanegowania relacji z innymi ludźmi oraz ignorowania ich celów (...); prowadzi do niepożądanych konsekwencji, takich jak negatywny stosunek do ludzi, czemu towarzyszy wdawanie się w konflikty, destrukcyjne zachowania o charakterze dominacji, zemsty i zimnego traktowania innych, opór przed poszukiwaniem wsparcia społecznego i brak umiejętności społecznych" (Wojciszke, 2010: 173). W skład skali niepohamowanej orientacji sprawczej wchodzą takie postawy, jak: skupianie się na realizacji swoich zadań tak bardzo, że zapomina się o reszcie świata; realizowanie swoich celów niezależnie od tego, co inni

\footnotetext{
${ }^{4}$ Niniejsze kategorie zbadane zostały za pomocą kwestionariusza opinii o sobie autorstwa B. Wojciszke (2010).
} 
pomyślą; poświęcanie zbyt małej ilości czasu na zajmowanie się problemami innych (zob. Wojciszke, 2010).

Niepohamowana wspólnotowość oznacza natomiast „tak silną koncentrację na innych ludziach i relacjach z nimi, że prowadzi do zanegowania własnej sprawczości oraz do zaprzestania realizacji własnych celów (...); prowadzi do niepożądanych konsekwencji, takich jak niedomaganie się wsparcia społecznego od bliskich (co skutkuje brakiem owego wsparcia) i destrukcyjne zachowania w bliskich związkach, takie jak nadopiekuńczość, inwazyjne, bo nadmierne wkraczanie w życie partnera, nadmierna kontrola partnera" (Wojciszke, 2010: 174). Niepohamowana orientacja wspólnotowa ujawnia się poprzez takie postawy, jak: stawianie potrzeb innych nad własnymi; brak umiejętności odmawiania, gdy ktoś prosi o pomoc; stawianie dobrych relacji z innymi przed sukcesem (zob. Wojciszke, 2010).

Orientacje sprawcze i wspólnotowe stanowią niejako pokłosie sposobu interpretacji zachowań jednostkowych, wynikają zatem z wyjaśnienia przyczyn danego zachowania (atrybucje zewnętrzne lub wewnętrzne), jak również $z$ innych mechanizmów psychospołecznych rządzących ludzkimi działaniami oraz poglądami (np. schematy i skrypty poznawcze). Autor wyjaśnia, iż „nasze postępowanie bardziej zależy od tego, jak swój świat rozumiemy, niż od tego, jaki ów świat w istocie jest. Co prawda, sposób rozumienia świata w dużym stopniu odzwierciedla rzeczywistą jego naturę, ale w pewnej mierze zależy także od zawartości i stanu umysłu człowieka, wskutek czego ta sama sytuacja bywa różnie odczytywana przez różnych ludzi, a nawet przez tego samego człowieka przy różnych okazjach. Powodem tego zróżnicowania jest odmienność struktur umysłowych, do których ludzie się odwołują, interpretując znaczenie obserwowanych wydarzeń czy próbując zrozumieć zachowanie spotykanych przez siebie osób” (Lewicka, Wojciszke, 2000: 27).

Postrzeganie współczesnej młodzieży przez przedstawicieli tejże kategorii pokoleniowej powiązane jest $\mathrm{z}$ tendencjami sprawczymi oraz wspólnotowymi. Ze względu na powyższe kwestie, realizowane badania własne, których wyniki przestawione zostaną w niniejszym artykule ${ }^{5}$, miały na celu diagnozę owych ukierunkowań, dzięki czemu możliwe było również zbadanie postawy młodzieży wobec sprawczego/wspólnotowego wymiaru funkcjonowania człowieka. Cel ten został zrealizowany za pomocą narzędzia badawczego opracowanego przez B. Wojciszke

\footnotetext{
${ }^{5}$ Badania zostały zrealizowane w 2013 roku za pomocą kwestionariusza ankiety. Z populacji generalnej wyłoniona została grupa osób biorących udział w badaniu - 439 uczniów klas I-III szkół średnich różnego typu (liceum, technikum, szkoła zawodowa) zlokalizowanych na terenie województwa Wielkopolskiego, umiejscowionych na terenie Poznania, Kościana, Opalenicy, Rokietnicy oraz Pobiedzisk Letniska.
} 
w postaci kwestionariusza samoopisu, który bada skalę sprawczości oraz wspólnotowości za pomocą trzydziestu określeń różnorodnych cech, wobec których osoby badane ustosunkowują się poprzez deklarację nasilenia owej cechy.

\section{Prezentacja i analiza wyników badań własnych}

Wyniki badań własnych, ujawniające ogólne średnie skal sprawczości i wspólnotowości, wykazały wyższy wskaźnik wspólnotowości $(4,10)^{6} \mathrm{w}$ porównaniu do sprawczości $(3,83)$ deklarowany przez respondentów. Można zatem domniemywać, iż wśród badanej młodzieży przeważa tendencja do koncentracji na pozostałych członkach systemu społecznego oraz podejmowaniu działań służących nawiązaniu poprawnych relacji z innymi. Skłanianie się respondentów w stronę orientacji sprawczej wynika być może ze specyfiki przeżywanego przez nich aktualnie etapu rozwojowego, jakim jest adolescencja, kiedy to wzrasta znaczenie uczestnictwa w grupach społecznych. Grupy te pełnią bowiem szereg funkcji, które służą realizacji zadań rozwojowych, rozumianych przez Roberta J. Havighursta jako „zbiór sprawności i kompetencji nabywanych przez jednostkę w trakcie jej kontaktów z otoczeniem" (za: Brzezińska, 2004: 224). Niniejsza definicja jednoznacznie podkreśla znaczenie otoczenia społecznego dla rozwoju osobowego młodzieży, która stojąc przed zadaniem kształtowania własnej tożsamości, odnosi się do grupy społecznej po to, aby móc ustrukturyzować się w rzeczywistości społecznej, przejść od egocentryzmu do socjocentryzmu (określenie Ireny Obuchowskiej), rozumianego jako poczucie bycia istotnym elementem współtworzonej społeczności. Owo przejście stanowi istotę okresu adolescencji, zatem wyniki badań własnych, ujawniające przewagę wspólnotowości w stosunku do sprawczości (która była domeną mniejszej części osób badanych), wykazały, iż respondenci są aktualnie na etapie „pomiędzy” egocentryzmem a socjocentryzmem. Deklarowane przez nich poczucie wspólnotowości, wyrażające się w rozumieniu działań innych, chęci współpracy, nastawieniu na korzyści grupowe, a nie jednostkowe, oznaczać może również identyfikację z grupą społeczną oraz rozumienie zjawisk społecznych przez pryzmat większego wpływu zależności międzyjednostkowych aniżeli indywidualnych dążeń czy potrzeb.

Wyniki badań własnych, mówiące o przewadze kategorii wspólnotowych, stanowić mogą potwierdzenie tezy o silniejszej dostępności niniejszych właściwości

\footnotetext{
${ }^{6}$ Wartości podane są w postaci średniej arytmetycznej.
} 
w pamięci oraz większej ich istotności w procesie postrzegania siebie i innych, co wyraża się interpretacją zachowań jednostki na podstawie jej relacji z innymi. Zatem można sądzić, iż badana młodzież bardziej ceni i rozwija te cechy osobowościowe oraz style zachowań, które wspierają jednostkę w harmonijnym połączeniu indywidualnych celów $\mathrm{z}$ interesem społecznym ${ }^{7}$.

Rezultaty badawcze wykazały, iż orientacje sprawcze/wspólnotowe są powiązane z płcią ${ }^{8}$. Wśród grupy badanej dziewczęta częściej od chłopców ujawniały dążenia wspólnotowe (dziewczęta - 4,27; chłopcy - 3,92). Zatem respondentki częściej od respondentów postrzegają siebie jako podmioty życia społecznego, realizujące się na obszarze uczestnictwa w grupie społecznej oraz międzyjednostkowych powiązań zmierzających do działania na jej rzecz. Powyższe tendencje wynikać mogą z odmiennej względem płci jakości oddziaływań socjalizacyjnych oraz zróżnicowań natury osobowościowej, jak również ze stereotypowego postrzegania roli społecznej kobiety/mężczyzny. Na różnice międzypłciowe w kontekście sprawczości/wspólnotowości zwrócił uwagę B. Wojciszke, uznając powiązanie stereotypu męskości ze sprawczością, natomiast kobiecości ze wspólnotowością, za wynik społecznego postrzegania, które potępia u kobiet zachowania sprawcze, natomiast u mężczyzn pochwala obie kategorie, traktując je jako ich indywidualny wybór. Teza B. Wojciszke, mówiąca o częstszym ujawnianiu przez kobiety orientacji wspólnotowych, natomiast przez mężczyzn orientacji sprawczych, znalazła potwierdzenie w wynikach badań własnych.

Dokonując analizy kategorii sprawczości niepohamowanej oraz wspólnotowości niepohamowanej w świetle wyników badań własnych, warto zauważyć, że B. Wojciszke wskazuje na silniejsze powiązanie wspólnotowości umiarkowanej z niepohamowaną aniżeli sprawczości umiarkowanej z niepohamowaną. Znajduje to potwierdzenie w wynikach badań własnych, gdzie wyższą średnią osiągnęła kategoria wspólnotowości niepohamowanej $(3,36)$ w porównaniu do sprawczości

${ }^{7}$ Ze względu na podjęty problem badawczy oraz jego rezultaty, interesujące są wyniki badań Agnieszki Cybal-Michalskiej nad indywidualizmem i kolektywizmem współczesnej młodzieży (zob. Cybal-Michalska, 2006).

${ }^{8}$ Średnia mówiąca o skali wspólnotowości w grupie dziewcząt wynosi 4,27; natomiast chłopców 3,92. Badana grupa młodzieży była proporcjonalnie zrównoważona pod względem płci: $51,3 \%$ stanowili chłopcy, 48,1\% stanowiły dziewczęta. W celu określenia związków pomiędzy zmiennymi, zostały zastosowane określone procedury statystyczne: model regresji (R), oparty na wybranej metodzie wprowadzania, biorącej pod uwagę wpływ wszystkich zmiennych uwzględnionych w modelu z wyjątkiem kategorii referencyjnych; korelacja rangowa, wyznaczona w oparciu o współczynnik korelacji rangowej Rho - Spearmana (S). Określono poziom istotności statystycznej o wartości p $<0,05$, którą przyjmuje się w naukach społecznych. 
niepohamowanej $(2,95)$. Należy przypomnieć, iż umiarkowana orientacja sprawcza wynosiła 3,83, natomiast umiarkowana orientacja wspólnotowa wynosiła 4,10. Wyższa średnia niepohamowanej orientacji wspólnotowej może oznaczać, iż jednostki w większym stopniu potrafią zrównoważyć bilans pomiędzy dążeniami indywidualnymi a grupowymi, ujawniając tendencje sprawcze, w porównaniu do wspólnotowego wymiaru postaw interpersonalnych, kiedy to łatwiej jest dokonać przejścia $\mathrm{z}$ jego optymalnego do niepohamowanego charakteru. Zatem można domniemywać, iż cechy świadczące o ujawnianiu orientacji wspólnotowej wywierają istotniejszy wpływ na (re)konstrukcje (Agnieszka Gromkowska-Melosik) poglądów podmiotu oraz jego stylu życia, jak również stanowić mogą bodziec tak silny, że jednostka w większym stopniu „narażona” jest na „niepohamowanie się” we wspólnotowości (w porównaniu do „niepohamowania się” w sprawczości), co skutkować może negatywnymi konsekwencjami dla funkcjonowania jednostki. Badana młodzież częściej ujawnia niepohamowane orientacje wspólnotowe, zatem można sądzić, iż częściej neguje własną sprawczość na rzecz silnej koncentracji na relacjach z innymi, co może prowadzić do zaprzestania realizacji indywidualnych celów i przewagi ujawniania "myślenia grupowego" kosztem ujawniania swoich osobistych poglądów. Niniejsza postawa może pełnić rolę tożsamości nadanej (James Marcia), przez co młodzież może zaprzestać podejmowania działań zmierzających ku osiągnięciu tożsamości dojrzałej. Zbyt silne poczucie wspólnotowości może niejako zwalniać młodzież z konieczności podjęcia własnych, indywidualnych poszukiwań odpowiedzi na pytanie: „kim jestem?”, co można uznać za czynnik hamujący rozwój.

Wyniki badań własnych wskazują iż chłopcy przejawiają wyższy poziom niepohamowanej orientacji sprawczej $(3,04)$ w porównaniu do dziewcząt $(2,86)$. Dokonując analizy wyników badań własnych w postaci średniej niepohamowanej orientacji wspólnotowej pod względem płci, można zauważyć, iż to dziewczęta osiągnęły wyższy wynik $(3,45)$ w porównaniu do chłopców $(3,27)$. Fakt ten pozwala wnioskować, iż różnice międzypłciowe widoczne są nie tylko w ramach sprawczości i wspólnotowości, ale także w ich niepohamowanych postaciach. Zatem można domniemywać, że stereotypy oraz czynniki socjalizacyjne są silnymi determinantami prezentowanych wymiarów spostrzegania społecznego oraz stylów zachowań. Wyniki badań własnych ujawniły coraz większy zwrot mężczyzn ku sprawczości, prowadzący do jej niepohamowanej postaci, oraz coraz większy zwrot kobiet $\mathrm{w}$ stronę wspólnotowości, prowadzący do jej niepohamowanej postaci. Oznaczać to może, iż wśród badanych występuje silna tendencja ku jednoznacz- 
nemu określeniu własnego Ja oraz nadawania swojej osobowości silnego rysu poprzez rezygnację $\mathrm{z}$ umiarkowanych skal ujawniania własnej osoby na tle relacji $\mathrm{z}$ innymi.

Biorąc pod uwagę deklarowane przez respondentów warunki materialno-bytowe rodziny ${ }^{9}$, zauważalna jest najwyższa średnia skali sprawczości niepohamowanej u osób deklarujących bardzo dobrą sytuację finansową, natomiast najwyższa średnia skali wspólnotowości niepohamowanej dotyczy respondentów określających warunki materialne jako złe. Zatem można uznać, iż sytuacja materialno-bytowa rodziny jest nie bez znaczenia dla ujawnianej orientacji sprawczej/wspólnotowej. Zwrot ku niepohamowanej orientacji wspólnotowej u osób mniej zamożnych może świadczyć o zachowaniu konformistycznym i asekuracyjnym, gdzie sprawczość traktowana jest jako zagrożenie dla bezpieczeństwa finansowego, $\mathrm{z}$ drugiej jednak strony może też stanowić skutek owej złej kondycji materialnej rodziny. Niemniej jednak, niniejsze powiązania warte są podkreślenia, bowiem stanowić mogą istotny czynnik w analizach dotyczących poczucia sprawstwa młodzieży jako czynnika wpływającego na sytuację materialną.

\section{Zakończenie}

Niniejszy artykuł, poświęcony orientacjom sprawczym/wspólnotowym młodych ludzi partycypujących w świecie płynnej nowoczesności, a oparty na wynikach badań własnych, wskazuje, iż jest to istotny element obrazu współczesnej młodzieży postrzeganego z perspektywy rówieśników. Dwukierunkowe relacje pomiędzy jednostką a otoczeniem społecznym sprawiają, iż warunki, w jakich partycypuje młodzież, mają wpływ na jej poglądy i dążenia, co uwidacznia się w wynikach badań własnych. Dążenia badanej młodzieży w kierunku wspólnotowego wymiaru relacji Ja - społeczeństwo można uznać za wyraz postrzegania własnych możliwości jako działań służących na rzecz szerszych grup społecznych oraz intensyfikacji

\footnotetext{
${ }^{9}$ Najliczniejszą grupę stanowili respondenci, którzy warunki materialne swojej rodziny określili jako dobre, czyli takie, które wystarczają nie tylko na zaspokojenie potrzeb egzystencjalnych, ale też potrzeb rozwojowych oraz/lub służą zwiększeniu stanu posiadania. Bardzo dobre warunki materialne rodziny, które dają możliwość zaspokojenia wyrafinowanych potrzeb oraz umożliwiają dynamiczne powiększenie stanu materialnego posiadania, zadeklarowało $22,2 \%$ osób badanych. Zdecydowanie mniej ogółu populacji badanej oświadczyło, że sytuacja materialna jest przeciętna (9,8\%), czyli taka, że środki materialne pozwalają jedynie zaspokoić podstawowe potrzeby egzystencjalne. Jedynie $0,9 \%$ respondentów wskazuje na złe warunki materialne rodziny, to znaczy takie, że środki finansowe nie wystarczają na zaspokojenie podstawowych potrzeb egzystencjalnych.
} 
jakości relacji międzyludzkich. Wyniki badań własnych wykazały, iż powiązania na linii jednostka - społeczeństwo ukierunkowane na wspólnotowość nie stoją w sprzeczności $\mathrm{z}$ indywidualistycznymi tendencjami stanowiącymi cechę konstytutywną czasów ponowoczesnych.

Podsumowując podjęte rozważania, pragnę podkreślić, iż refleksje nad orientacjami sprawczymi/wspólnotowymi współczesnej młodzieży stanowić mogą płaszczyznę do dalszych dyskusji nad jej kondycją w świecie permanentnej zmiany, co nabiera szczególnego znaczenia, gdy postrzega się młodzież jako aktywną grupę społeczną stanowiącą podmiot zachodzących zmian społeczno-kulturowych.

\section{Literatura}

Bauman Z. (2006). Płynna nowoczesność, przeł. T. Kunz. Kraków.

Beck U. (2002), Społeczeństwo ryzyka. W drodze do innej nowoczesności, przeł. S. Cieśla. Warszawa. Brzezińska A. (2004). Społeczna psychologia rozwoju. Warszawa.

Buczkowski P., Cichocki R. red. (1998), Podmiotowość. Możliwość - rzeczywistość - konieczność. Poznań.

Cichocki R. (2003). Podmiotowość w społeczeństwie. Poznań.

Cybal-Michalska A. (2006). Tożsamość młodzieży w perspektywie globalnego świata. Poznań.

Giddens A. (2003). Stanowienie społeczeństwa. Zarys teorii strukturacji, przeł. S. Amsterdamski. Poznań.

Giddens A. (2010). Nowoczesność i tożsamość: „Ja” i społeczeństwo w epoce późnej nowoczesności, przeł. A. Szulżycka. Warszawa.

Hannerz U. (2006). Powiązania transnarodowe, kultura, ludzie, miejsca, przeł. K. Franek. Kraków.

Jarymowicz M. (1984). Spostrzeganie własnej indywidualności. Wrocław.

Karmolińska E. (2006). Młodzież ze środowisk zagrożonych marginalizacja wobec własnej przyszłości. Poznań.

Lewicka M., Wojciszke B. (2000). Wiedza jednostki i sady o świecie społecznym. [W:] Psychologia, t. 3. Red. J. Strelau. Gdańsk, s. 25-76.

Peret-Drążewska P. (2014). Wspótczesna młodzież postrzegana z perspektywy rówieśników. Studium teoretyczno-empiryczne. Poznań.

Reykowski J. (1998). Podmiotowość - szkic problematyki podmiotowości. [W:] Podmiotowość. Możliwość - rzeczywistość - konieczność. Red. P. Buczkowski, R. Cichocki. Poznań, s. 199-212.

Reykowski J. (1999). Kolektywizm i indywidualizm jako kategorie opisu zmian społecznych i mentalności. [W:] K. Gawlikowski [et al.], Indywidualizm a kolektywizm. Warszawa, s. 23-51.

Reykowski J., Skarżyńska K., Ziółkowski M. red. (1990). Orientacje społeczne jako element mentalności. Poznań.

Sztompka P. (1998), Socjologiczna teoria podmiotowości. [W:] Podmiotowość. Możliwość - rzeczywistość - konieczność. Red. P. Buczkowski, R. Cichocki. Poznań, s. 11-28. 
Wojciszke B. (2010). Sprawczość i wspólnotowość. Podstawowe wymiary spostrzegania społecznego. Gdańsk.

Zamojska E. (1998). Kulturowa Tożsamość młodzieży: studium empiryczne: z badań nad młodzieża szkót średnich. Poznań - Toruń.

\section{Causative and Community Orientations of Contemporary Youths}

\section{Summary}

The essential element of unit's participation in socio-cultural life is the quality of relations between individual endeavours and needs of social groups which sets the perception of other people. Participation in the social world makes the functioning of subjects shaping its appearance in dualistic way, because on one hand, people are oriented in realisation of individual aims, where on the other hand they are required to fulfill the tasks that help the interests of social life which we all co-create. Both forces are the ground for any human actions, turned more in the direction of personal implementation or community's aims. That issue was the main plot of thorough teoretical analysis and emphirical studies made by B. Wojciszke, who sees those cathegories as basic dimentions of social perception, named causativity and communality. Those definitions were borrowed from D. Bakana who took them as different dimentions of human existence.

B. Wojciszke definies the causative cathegory as , an expression of human existance as a different unit, efforts to individuation and separation by implementing their own goals, self-confidance and the 'I' expantion; bindes to the focus on yourself and and domination. The causative people are the units who have dominant motives of achievement, domination and independence". Whereas communalism is ,an expression of human existance as a part of bigger organism, efforts to integrate with social beings, by caring for others and collaborating; binds to the focus on others, caring for them and intimacy. The community people are units who have dominant motives of intimacy and affiliation". The unit, being a part of social relations adapt and attitude aimed at taking action which leads to achieving a personal goal (advantage of communality) or also aimed at understanding the actions of others (advantage of causativity). Then ,casuative and communality cathegories are the basic cathegories of description and evaluating people" - as written by B. Wojciszke.

The perception of today's youth made by representatives of that generational cathegory is linked to the causative and community tendencies. Due to that issue, performed research of which results will be presented in this chapter, was aimed at the diagnosis of those orientation, that as well can show the attitude of youth towards causative/community dimention of human functioning. That aim was realized with the help of a research tool developed by B. Wojciszke in the form of questionnaire of selfdiscription, that tests the scale of causativity and communality by using 30 various terms of features to which the subjects relate to, by declaring the intensity of that feature.

The results revealing the general average scale of causativity and community, declared by the respondents showed a higher rate of communalism $(4,10)$ than causativity $(3,83)$. Therefore it can be assumed that among those young people the prevailing tendency is to concentraite on other members of social system and taking action to establish the correct relations with others. Based on, resulting 
from the research dominance of intensity community's orientation of respondents, it can be prejudged about the greater relevance of negative information in assesing the behavior based on specific properties, which leads to form of limited trust and secure behavior that requires you to refuse positive features in process of viewing people. In case of community orientation, the power of negative properties is bigger, therefore the general negative conclusion is drawn more often. The results showing the superiority of community cathegory, confirm the thesis of stronger availability in mind of those properties and their bigger significance in process of viewing yourself and others, which reflects on the interpretation of people's behavior based on those properties.

The outcome of research has shown that the causative/community orientations are linked with gender. Among the studied groups, girls showed the community aspirations more often than boys. Therefore female respondents see themselves as subjects of social life, persuing participation in the area of a social group and the inter-individual links that are aimed at actions for it's benefits. The above tendencies may be the results of the opposite in gender quality of social impacts and the differences in personality. The foregoing considerations were related to moderate forms of causativity and communit, that do not lead to positive consequences. However, there are situations when those unwanted consequences do happen. Therefore in addition to the moderate forms of causativity and community orientations, their extreme forms named as unrestained causativity and community orientations were specified. Those cathegories have been examed using questionnaire about opinion of myself by B. Wojciszke.

B. Wojciszke interprets the unrestrained form of causativity as „focus on yourself and your own goals being so strong (unrestrained by community's requirements), that it leads to a denial of relations with other people and ingnoring their goals (...), leads to unwanted consequences such as negative attitude towards people, accompanied by elaborating in conflicts, destructive behaviors of dominant nature, revenge and giving people the cold shoulder, resistance in seeking social support and lack of social skills". Whereas unrestrained community means „that strong focus on other people and relations with them, that it leads to unwanted consequences such as not demanding a social support from loved ones (which effects in lack of that support) and disruptive behavior in close relatinships, like overcaring, invasive - because excessive entering in partner's life, and partner's excessive control". B. Wojciszke highlights the stronger link of moderate community with unrestrained and not the moderate causativity with unrestrained.

This is confirmed in the results of research, where higher average was achieved by the cathegory of unrestrained community $(3,36)$ in comparison to unrestrained causativity $(2,95)$. It should be noted taht moderate causative orientation was 3,83 while moderate community orientation was 4,10 .

Boys show higher level of unrestrained causative orientation $(3,04)$ compared to girls $(2,86)$. Analysing the results in the form of average unrestrained community orientation, considering gender, it can be seen that girls achieved higher results $(3,45)$ than boys $(3,27)$. Considering the material and living conditions of family, declared by the respondents, directly proportional growth tendency in the area of unrestrained causativity and community is noticable. Summing the foregoing considerations, emphasized should be the high level of moderate community orientation of residents, which is an important information in the research of image of today's youth as seen from the peers' perspective.

This article on causative/community orientation of young people participating in the world of modernity in the light of results, indicates that it is a significant element of the today's youth image seen from the peers' perspective. two-directional relations between a unit and social environment cause the conditions in which th youth participates have an impact on their views and aims, which 
reflects on the results. Aspirations of the tested youth in direction of community dimention of me society relations can be taken as perception of their abilities, as actions aimed in favor of wider social groups and intensification of the quality of interpersonal relations. In the light of results, the links between the unit and society, directed at communalism, are not in conflict with the individualistic tendencies forming a constitutive feature of post-modern times.

Reflections on the causative/community orientation of today's youth can be the ground to further reflections on its condition in the world of permanent change, which aquires a particular meaning in viewing the youth as an active social group, being the subject of ongoing socio-cultural changes. 